\title{
The problem with relying on dietary surveys: sociocultural correctives to theories of dietary change in the Pacific islands
}

Background: Dietary surveys are frequently used as the basis for theorising nutritional change and diet-related non-communicable disease emergence (DRNCD) in the Pacific islands. However, findings from historical survey data do not always align with ethnographic evidence.

Aims: This paper aims to examine the extent to which the two types of evidence can lead to similar conclusions, and draw out the implications for current theories of, and interventions addressing, nutritional change.

Subjects and methods: Dietary surveys carried out on Nauru between 1927 and 1979 are reviewed and compared with ethnographic evidence documented by social researchers across the colonial and post-colonial periods.

Results: This comparison reveals several shortcomings of survey data. Nutritional issues considered to be relatively recent - such as high-fat, low-fibre diets and transition to imported foods - occurred a century ago in our analysis, and point to a long history of nutrition policy and intervention failure. Further, there is limited evidence that caloric intake overall has increased significantly over this period of time in Nauru.

Conclusions: Theories of dietary change and DR-NCD emergence, and resulting interventions, could be improved through a more holistic approach to nutrition that integrates sociocultural and historical evidence about both the target population and the scientists doing the research.

Keywords: non-communicable disease; Pacific islands; dietary survey; ethnography; nutritional change 


\section{Introduction}

Understanding history and social change is important for explaining the emergence of obesity and diet-related non-communicable diseases (DR-NCDs) (McLennan \& Ulijaszek 2014a). This is especially the case in the Pacific islands, which experience some of the highest rates of obesity in the world (McLennan \& Ulijaszek 2014a). Yet in nutritional research, some types of historical evidence are privileged while others remain under-used. In this paper, we compare dietary survey data on the one hand, and historical ethnographic and sociocultural data on the other, to examine the extent to which they align or contradict each other. Misalignment raises questions about which of the two methods is better, and under what circumstances. We go on to assess whether a more interdisciplinary approach that incorporates both forms of evidence could improve our understanding of dietary, nutritional and health problems, and the interventions we design as a result.

Theories and ideas of dietary change and DR-NCD emergence, such as nutrition transition (Popkin et al. 2012), thrifty genotype (Neel 1962) and others (Ulijaszek 2007), all draw on survey data to investigate changing food environments and consumption patterns over time. Although they provide broad descriptions of historical and social change, these theories typically rely on a limited range of historical and social evidence, usually historical surveys, questionnaires and other quantitative data sets. These data sources provide very limited social and cultural evidence about the lives, traditions and habits of the people surveyed, or their relationships with the people carrying out the research. Yet theorists of nutritional change often rely on nutritional survey data to make broad inferences about the ways societies and cultures have changed, and in particular how food preferences, values and practices have changed. For example, Popkin bases his idea of nutrition transition on large, nationally- 
representative or nationwide surveys, combined with food balance sheets and national income accounts (Popkin 1998). Ulijaszek and Koziel likewise theorise dietary change, lifestyle change and nutrition transition in Eastern Europe after the fall of communism using large national and international datasets (Ulijaszek \& Koziel 2007). While the drawbacks of data collection methods have been discussed (e.g. Grandjean 2012), the drawbacks of only relying on a narrow diversity of types of evidence has been less well considered.

The Republic of Nauru is another example where this has occurred. Nauru was one of the sentinel cases of emergent population-wide DR-NCDs; for this reason, the history of how nutritional health concerns such as obesity and diabetes became defined there is important. Obesity is disproportionately prevalent in the small island nation of Nauru (Finucane et al. 2011), and the low life expectancy of Nauruan people has been largely attributed to the emergence of NCDs in the latter part of the twentieth century (Taylor \& Thoma 1985; Carter et al. 2011). Longitudinal studies of obesity and other DR-NCDs in the Republic of Nauru have been based on historical food data, such as the population's diet and food imports. The common perception in these studies is that the rise in obesity rates on Nauru can be explained by the dietary shift from high-fibre to low-fibre diets (Ringrose \& Zimmet 1979), a shift away from traditional food practices (Diamond 2003) and the rise of high-energy food imports and high-calorie diets which coincided with political independence and economic wealth in the 1960s and 1970s (Balkau et al. 1985; Win Tin et al. 2014). These explanatory models and theories are largely based on just three dietary surveys carried out by non-Nauruans in the last century (Bray 1927; Kirk 1957; Ringrose \& Zimmet 1979). Despite their limited scope and sample size, as well as limited view of seasonal fluctuations in diet, these surveys have been the foundation of the nutrition narrative common to Nauru and, as a result, many other 
Pacific Islands: that DR-NCDs emerged in the second half of the twentieth century due to increased caloric intake from imported food products. This narrative underpins many current health policies and interventions in Nauru and beyond.

Our analysis shows that if different forms of data are introduced as comparators, the picture changes. In this paper we interrogate and contextualise historical survey and questionnaire data with historical ethnographic and sociocultural evidence such as oral histories, participant observation and archival material. These sociocultural forms of evidence - about both the local population and of the governing power and/or researcher(s) - can be used to refine theories of dietary and health change. They also reveal the limitations of grand narratives linking food imports and modern consumption practices with obesity and DR-NCDs. Without sociocultural evidence, the social must be inferred and can reflect the cultural biases of the theorist, albeit unintentionally. This may lead to interventions which are ineffective or have unintended negative consequences (for example, see McLennan 2017).

\section{Materials and methods}

\section{Review of formal dietary surveys}

All dietary surveys available for Nauru between 1900 and the present were identified and both the numbers and text analysed. Three major surveys were identified for 19271979 (Bray 1927; Kirk 1957; Ringrose \& Zimmet 1979), and these form the basis of analysis in this paper. They are summarised in Table 1 . Additional nutrition data have been collected through national health surveys carried out in the country since that time, including the World Health Organisation STEPS surveys (Government of Nauru \& World Health Organisation 2007) and the Government of Nauru and Secretariat for the Pacific Community’s Demographic and Health Survey (Nauru Bureau of Statistics et al. 
2009), both carried out in 2007. Our review included (re)analysing results presented in the surveys from 1927-1979, as well as reviewing the context in which surveys were carried out. A principal aim of the latter was to understand the field of expertise, objectives and possible assumptions of the people who carried out the surveys, as well as their relationship with, and knowledge of, the surveyed population.

\section{Archive searches for additional dietary data}

MS searched the British Library catalogue using the search term "Nauru AND report". Relevant items were consulted, and data collected using a camera phone. Additional data identified are summarised in Table 2.

\section{Historical ethnographic and sociocultural data}

To complement and/or interrogate the survey data we draw on historical ethnographic evidence, including material collected using the methods of participant observation and oral histories. Participant observation, such as shopping, cooking and eating with people, enables researchers as 'outsiders' to understand some aspects of the 'inside' life of different social groups (e.g. families, villages), including implicit rules, habits, social practices, shared meanings and possible challenges entailed in activities such as food provisioning. Life history interviews widen researchers' understandings of how particular social phenomena, such as food consumption, have changed over a person's lifetime, as remembered and narrated by local people. These methods of data collection and analysis are described more fully elsewhere (McLennan \& Ulijaszek 2014a; McLennan 2017). Many ethnographic findings we use in the present paper have been published elsewhere.

Some material in this paper is sourced from AKM's ethnographic research on Nauru. 
Ethics approval for the research was granted by the University of Oxford’s Central University Research Ethics Committee (CUREC). Pseudonyms for Nauruan people are used throughout this paper in order to conceal their identities.

\section{Results}

\section{Bray's survey (1927): a colonial benchmark}

Records suggest that Nauru was first 'discovered' by John Fearn, a British whaling ship captain, in 1798. Following the Anglo-Germany convention in 1888, Nauru fell under German administration. Missionaries first arrived on the island 1889, with Reverend Philip Delaporte and his wife, Salome, making concerted efforts to improve Nauruans' customs and behaviour success (Delaporte 1920). British surveyor Albert Ellis arrived on Nauru in 1900 and, following investigation, discovered that Nauru was a rich source of high-grade phosphate. The Pacific Islands Company (PIC) for whom he worked negotiated rights to exploit the island's phosphate. Not long thereafter the PIC was wound up and the Pacific Phosphate Company (PPC) was formed to carry on the work (Weeramantry 1992).

After World War I, Nauru fell under a Class C League of Nations mandate. ${ }^{1}$ It was no accident, given the nations' knowledge of Nauru's rich mineral resources, that responsibility for administration fell to Australia, Britain and New Zealand. The PPC was sold, and mining rights transferred, to the British Phosphate Commission - a creation of the three governments, where each nominated a Commissioner and many of

\footnotetext{
${ }^{1}$ Australia was in effective control and provided the Administrator, formally together with the Britain and New Zealand, from 17 December 1920. On 1 November 1947 it was made into a United Nations Trust Territory (under the same three powers), an arrangement which persisted until its political independence as a republic on 31 January 1968.
} 
the executive were transferred from the PPC (Weeramantry 1992). Partner governments were all answerable to the League of Nations for discharge of their mandate, where Article 22 required that:

to "peoples not yet able to stand by themselves under the strenuous conditions of the modern world there should be applied the principle that the well-being and development of such peoples form a sacred trust of civilisation” (Weeramantry 1992, p27).

Over the subsequent decades, correspondence in Australian archives illustrates how the governments discharged their mandate in a way that also kept in mind the need to ensure ongoing and unmitigated future access to the phosphate.

As an Administering Authority, Australia was required to provide annual reports to the League of Nations to show that they were taking adequate care of the native population and making improvements compared to the previous colonial power, Germany. In addition to annual reports summarising all aspects of Nauruan life (including health, imports, taxes, education and housing), Australian authorities on the island occasionally carried out more in-depth investigations.

Colonial attention towards islanders’ wellbeing was not limited to Nauru. World War I had brought new infectious diseases to many of the islands in the Pacific, including influenza, and many islanders perished. In opening the International Pacific Health Conference in Melbourne in 1926, Acting Prime Minister Earle Page outlined the Commonwealth’s approach to the Pacific islands, stating

"We, in the Commonwealth, feel strongly that the time has arrived for a more comprehensive survey of our common difficulties, and for a more cohesive relationship for the better discharge of our common responsibilities in the Pacific region... and in all common ways we 
should seek to help each other in our common task of securing and improving the health and happiness of those people for whom we are responsible” (Bray 1927, p5).

This support for wellbeing included encouraging population growth and survival of the population; the first census on Nauru was taken in 1921, and the people of Nauru were encouraged to aim to achieve a population of 1500 people as soon as possible. They achieved this in 1933, on a day still celebrated as Angam Day. At the same time, the islands were proving to be important strategic assets for Commonwealth powers expanding wireless networks and asserting their defensive posture in the region. Nauru was just one nation in the Pacific to which colonial powers turned their attention.

Australian George W. Bray was a colonial Medical Officer on Nauru and the author of the first dietary survey conducted on the island, in 1927. He began this work as soon as he had completed his medical course and commenced practicing medicine. His dietary research on Nauru was the basis for a research thesis to qualify him as a Doctor of Medicine at the University of Sydney. In this thesis, Bray set out to prove three things: first, that dietetic deficiency on Nauru was the reason for lack of resistance to infection and disease amongst Nauruans; second, that dietary change, towards 'scientific nutrition', could eliminate disease; and third, that infantile beriberi is a distinct clinical entity. Bray’s thesis question was: ‘Is Australia recognising her obligation to her dependent native races?' The report was also intended to inform Australian authorities and the League of Nations about Nauruan health and make recommendations for dietary improvement. In this way, this survey was simultaneously a way for authorities to demonstrate their care for the local population to the League of Nations, in order to ease progress towards escalating mineral exploitation of the island.

Bray was quick to distinguish himself from the local population, and in doing so raises 
doubts about his ability to access or carefully document local food practices. In introducing his work, he describes white man’s ‘superior intellectual equipment, with his more elaborate language and means of communication', and describes white man's responsibility towards the Nauruan natives. He also describes the lives of Nauruan people in a way that suggests more of an interest in changing them rather than listening and learning from them:

But, at the outset, it is necessary to realize that the Nauruans are not toilers, but rather of the nature facultative parasites, living as wealthy landowners in idleness and comfort on the moneys earned by the Chinese wage-slaves. In such an outlook on life lies the basis of their susceptibility to disease (p5-6).

This quote reflects strong Western moral values of hard work, where work is construed as an economically-gainful employ rather than, for example, Nauruan activities of building and maintaining social and community networks (McLennan 2013). Bray does not note the colonial administration's interest in ensuring the people of Nauru remain distanced from the mines, nor the irony that the (higher-status) wealthy white population on the island led by example with similarly comfortable lifestyles in relatively well-appointed houses.

Bray’s approach involved describing the typical Nauruan diet, identifying deficiencies in the diet and quantifying the diet in terms of nutritional value. He surveyed the typical Nauruan diet based on 'a consideration of numerous diets investigated at random' (Bray 1927). He recorded the average weight and nutritional value of each food item consumed and the total weight of daily food consumption (Table 1). The published report does not specify the number of people Bray surveyed, the questions he asked, nor specifically where the surveys were carried out. Bray created data categories typical of 
Western dietary categories at the time: everyday food items and occasional delicacies. He identified six everyday food items: coconut milk, toddy, ${ }^{2}$ grated coconut, fish, pandanus, ${ }^{3}$ and biscuits, ${ }^{4}$ but noted that only up to three of these might be consumed in a day. He classified everything else as an occasional delicacy, with the exception of sugar.

Sugar is set separately because its use is partially alternative to the previous articles: Sugar enters to some degree into practically all diets, since coconut requires preparation, fish is not obtained everyday,

${ }^{2}$ Coconut is an important food in Nauru, and was an important staple until regular trading was established with European ships in the 1800s. The spathe of the coconut, or pod that forms around a palm flower, can be tapped to collect a sweet sap called toddy. Nauruans preserved toddy through a cooking process which concentrated the sugar and resulted in a thick redcoloured syrup, ekamwirara. This is distinct from three-day fermented toddy, which forms an alcoholic drink referred to as 'sour toddy'. Sour toddy was prohibited on Nauru by the German administration in the late 1800s (Stephen 1936).

${ }^{3}$ Pandanus fruit was an important staple carbohydrate in Nauru until regular trading was established with European ships in the 1800s. It was 'considered a more important food than coconuts, so much so that if a man possesses three acres of land he will plant two of them with pandanus' (Stephen 1936: 53). The fruit was made into a variety of products in big community events held in the centre of the island (Kayser 1934). Two key products were: edongo, dried pandanus-cake which looked like a strip of leather and reportedly tasted like dried figs; and ekareba, pandanus flour.

${ }^{4}$ Ship’s biscuits were a staple part of sailors' sea diets, especially prior to the introduction of canned foods. They are simple crackers made out of flour, water and sometimes salt and baked in a hot oven to harden and dry. They are very hard-wearing. People in Nauru today still eat a similar product - breakfast biscuits or crackers - today. 
pandanus only occurs in season, and biscuit does not always enter into the diet. When such conditions obtain the tendency is for sugar to replace one or all of the other articles and thus satisfy a natural craving. (p17)

According to Bray, sugar was used in preparing coconut, preserving fish, and to replace pandanus and biscuit; he does not mention sugary drinks such as tea, which appear later. Yet sugar intake does not feature in Bray's calculations other than in the consumption of foods such as pandanus, which contained sugar. A medical survey around the same time similarly cites the Nauruan diet as being based on toddy, 'together with coconut, coconut milk, rice, fish and cooked birds’ (Grant 1933). It makes no further mention of other foods.

There is some disjuncture between Bray’s categories of ‘everyday’ foods and his opening commentary and observations about disease in Nauru which, among other things, clearly mentions sugar and tinned meat.

The law denies them polished rice; the natives despise brown rice, but eagerly consume the sugar and tinned meat of which the law allows free right of purchase, and for which it provides ample royalties. Thus a vicious circle has been established: greater income leads to less consumption of wholesome native foodstuffs, greater ingestion of preserved innutritious European foods, and hence to greater idleness, lethargy and disease (p6)

There is also misalignment between Bray’s categories and Nauruan dietary practice recorded elsewhere. Wedgewood, who carried out fieldwork on Nauru in 1935, records multiple food items produced from pandanus and coconut, commenting that it 'would be tedious to enumerate here all the different ways in which the pandanus fruit and 
coconut were treated for food... [and] the ways in which fish were (and still are) caught are too numerous to be detailed'. She also describes contemporary cultivation of bananas, pumpkins, beans and fruit-bearing trees. Stephen describes the consumption of pork and shellfish in the early 1900s (Stephen 1936). Customs import records from the early 1920s record the import of over 60 food types, from vegetables (tinned and fresh) and meats to cakes, cheese and breakfast cereals (Administration of Nauru 1922).

Rice is noteworthy here. Today, rice is considered a 'staple' on Nauru, with a food event not being considered a meal if it does not contain rice. However, rice has never been cultivated on Nauru. It is unclear why authorities in the 1920s prohibited the people of Nauru from eating polished rice, at what stage they did so, or for how long the prohibition was upheld. It is possible that this regulation was introduced to limit supplies being passed from Chinese labourers, who arrived as mining labourers in 1907 and were segregated from the native population in an area of Nauru known as Location. Equally unclear is the level of success of the prohibition, as Bray did not consider it further. Oral histories recount (illegal) trade between the Chinese workers and Nauruan population, and rice may have been included in this.

Bray also noted signs of nutrient deficiency among the population. At the time, the importance of vitamins for nutrition had only just begun to be established; Bray reviews literature that emphasises only vitamins $\mathrm{A}$ and $\mathrm{C}$ to be necessary for infant feeding, and noted that 'the possibility of a B-factor deficiency seems to be set aside as irrelevant to the discussion of infant feeding' (p8). Furthermore, he noted that a key assumption of the medical profession - that the 'native living on natural products of the earth and sea does not suffer from deficiency diseases - suggesting that he perceived the Nauruan diet to be somewhat traditional, despite his earlier observations that large amounts of imported foods were freely consumed. Through his research, he argued that the rate of 
child mortality was due to a lack of Vitamin B, possibly due to reduced consumption of the pandanus (Kayser 1934) but more likely, he surmises, due to the administration’s banning of fermented toddy. ${ }^{5}$ Yet, somewhat contradictorily, Bray found that pandanus was consumed more than any other 'everyday' commodity: up to 10 servings a day.

Equally confusing are his caloric estimates, which are so variable that it is difficult to assess the reliability of his nutritional analysis. According to Bray it is rare for more than three different food items from the everyday category to be consumed on any given day. But the caloric range of his three-item diets is very wide: from 697 calories to 2767 calories (the former is comprised of biscuit, pandanus and fish and the latter of coconut milk, toddy and grated coconut). Moreover, the daily sugar intake of Nauruans remains unclear, as according to Bray, sugar may have '[replaced] one or all of the other articles' (p17). If the three items consumed are low-calorie foods, it is possible that his estimation of 2,900 daily calories is high. On the other hand, if sugar does indeed replace a significant number of food items consumed, 2,900 daily calories may be a considerable underestimation. It follows that Bray’s estimations for fat, carbohydrate, protein and vitamins may also be inaccurate.

Bray noted that the Nauruan diet could be improved simply by changing colonial trade and governance practices. He made several recommendations relating to sugar and fibre intake: that condensed milk, because of its vitamins, should be introduced into the Nauruan diet; that the sale of sugar should be prohibited; and that brown rice and

\footnotetext{
${ }^{5}$ Pandanus fruit is carbohydrate-rich, as well as high in vitamin $\mathrm{A}$, fibre, iron, $\beta$-carotene equivalents, thiamine (vitamin B1) and ascorbic acid (vitamin C) (Pollock 1992: 250; Secretariat of the Pacific Community 2006: 2; see Appendix E for estimated nutritional values).
} 
wholemeal should be included in the diet. There is no evidence that any of these recommendations were implemented. Yet Bray’s nutritional analysis and recommendations suggest that current theories of dietary change, which call for a reversion to 'traditional' diets, are inaccurate. Bray's report suggests that imported diets were the norm in Nauru by the 1920s - two or three generations ago. This is in accordance with ethnographic evidence such as oral histories. Interviewed Nauruans born as early as the 1930s considered foods such as white rice and sugar to be 'traditional staples' of Nauru, although neither have ever been cultivated on the island (McLennan 2013). Foods become indigenised in many different ways, as local foodways and cultures come into contact with colonial, postcolonial, capitalist and market foods and forces, to create new meaning around new foods (Wilson 2017). Assumptions about 'traditional diets' assume that islands, and islanders, are isolated, and that clear distinctions can be made between imports and local foods. Such distinctions do not align with anthropological evidence of close global interconnectedness (McLennan \& Ulijaszek 2014a).

\section{Kirk's survey (1957): a colonial responsibility}

World War II, with occupation by Japanese forces, had profoundly detrimental effects on the Nauruan people and land. The population was decimated, once again dipping below 1500 people. There is mixed evidence about Nauruan diets at that time. Some authors claim that people survived on remarkably low rations of only a matchbox of rice per day (Pollock 1995; 2014), and argue that this underpins present-day obesity and diabetes. However, oral histories suggest that Nauruans' knowledge of the sea, friendship with Japanese forces and sharing as a community afforded them access to significantly more food than ration records suggested, including pumpkins and seafood. It is therefore difficult to draw firm conclusions about nutrition in this period. 
After the war, colonial domination of Nauru's resources and its people continued, as Nauru returned to similar governance arrangements, this time as a Trust Territory of the United Nations (Viviani 1970). Australian mining of Nauru’s precious phosphate recommenced and rates of extraction rose. With the improved education of some Nauruans (albeit accidentally - they had had to stay in Australian schools longer than expected on account of the war), and following the trauma of WWII, Nauruans redoubled their efforts to seek political independence. Yet it was in Australia's interest to ensure it maintained control over Nauru and its assets for as long as possible: archival colonial correspondence from the time emphasises the importance of cheap Nauruan phosphate to Australian agriculture (its largest economic sector) and outlines a range of strategies to ensure that the supply would continue. To do so, Australia benefited from providing evidence to the UN demonstrating its ongoing care for the local population.

Nancy E Kirk (now known by her married name of Hitchcock) was sent to conduct a dietary survey on behalf of the Australian Government. Kirk studied dietetics in 1951 at the Royal Newcastle Hospital (Scott 2015). In September 1957 she joined the Australian Government's Department of Health, in Canberra, as a senior nutritionist. Shortly thereafter she was sent to conduct a nutrition survey in Nauru. She spent four weeks on the island (personal communication).

Kirk aimed to provide comprehensive descriptions of typical housing, cooking and eating facilities and of food purchasing and storage tendencies, in order to provide insights into typical meal patterns and quantities of foods consumed. She surveyed a total of 181 women (and sometimes men) in thirty-two multi-family households (average six people per household; in Nauru, the concept of 'family' is much broader than the Western notion of 'nuclear family', so it is likely that the people Kirk surveyed did not consider themselves to be in multi-family households, but in a single family), 
and used thirty of these in her analysis (Kirk 1957). Kirk asked respondents their age, occupation, household income, food procurement strategies and typical meals and meal components. She used responses to the latter to form a series of typical sample diets based on income; she then extrapolated from these to calculate weekly food intake.

Kirk shaped her investigation and analysis around the Western unit of food and eating: the meal, a collective food event consisting of meat, vegetables and carbohydrate. This approach, here and in Papua New Guinea, was structured by her dietetics training, as was made clear to one of the authors of the current paper when he discussed her colonial survey work with her in 1985. Kirk’s approach did not take into account early records suggesting the people of Nauru had different food rhythms, such as seasonal patterns of feasting (especially around the time of pandanus harvests and large catches of flying fish) and up to weekly feasting events (Kayser 1934; Stephen 1936;

Wedgewood 1936a; Wedgewood 1936b). It equally did not consider that meal structures themselves might be different than in Australia; in much of the Pacific a food event might contain a starchy food with a small accompaniment of fish (Pollock 1986), and it is possible that Nauru is different again given its lack of starchy root crops. Early missionary records indicate that Western food habits were not the norm, but that colonial powers were actively attempting to teach the local population to follow them, with some success (Delaporte 1920).

Kirk also shaped her analysis around Western ideas of status, assuming that economic income correlated directly to higher wealth, status and access to goods. This contradicts observations that status, at the time, was associated with giving rather than accumulating material wealth (Wedgewood 1936b; McLennan \& Ulijaszek 2014b). The 'typical’ sample diets Kirk described ranged from three meals per day (amongst highest-income households) to less than one meal per day (amongst households with 
lowest income, which she described as being in extreme poverty). She does not report relative frequency of each, and she does not mention feasts or day-long food events which were not uncommon in Nauru, but having fewer than two meals per day appears to have been an exception. In addition, she does not describe how she counted intake of leftovers, with some three-meal households reportedly consuming leftovers from a previous meal for a subsequent one, rather than a new volume of food.

Kirk found that tea with milk and/or sugar was consumed up to four times per day in all households. Tinned beef and rice was consumed by all households, while fish and breakfast cereals were only consumed by some, onions and potatoes by others. Underpinning Kirk's analysis were the Recommended Dietary Allowances (RDA) of Australia, which were published in the Medical Journal of Australia in 1954 and based on the RDA issued by the National Research Council of the United States (Commonwelath of Australia 1991). She used these figures to extrapolate the average weight of weekly Nauruan consumption and nutritional values by income. Based on this calculation, Kirk reported that the average weekly intake of Nauruan households she surveyed was 11.61 pounds in weight, or 1.66 pounds/day. From this, Kirk determined that the daily caloric intake per person was 2,900 calories, with 43.5 grams of protein, 31.5 grams of fat, and 615.5 grams of carbohydrate.

Based on her analysis and comparison to Australian recommended dietary allowances, Kirk concluded that the Nauruan diet was significantly deficient in calcium, as well as vitamins A and C. As a result, Kirk recommended that fruit, vegetables, butter or fortified margarine and whole milk be introduced into the Nauruan diet. Although she recommended at least three pieces of fruit and four vegetable servings per person per week, she contended that the amount of produce grown locally was insufficient to meet those quantities and must therefore be imported. This is still the case today, although 
studies such as the WHO STEPS survey (2007) point out poor levels of fruit and vegetable consumption and recommend that people consume more, without acknowledging that regular access is almost impossible. Recommended Dietary Allowances (RDAs) in this way is a way of standardising food requirements at the nation-state level, and applying RDAs from the US (via Australia) is another colonial, or neo-colonial, instrument for the regularisation of food on Nauru.

Similar to Bray’s report thirty years earlier, Kirk found that the Nauruan diet originated from island stores with very few locally-cultivated foods. Kirk pointed out lack of arable land and suggested that Nauruan reliance on imports is because of need, not wealth and Western influence. Yet this overlooks two things: first, that the sea is as important a food source as the land, or potentially even more important in small island nations (the connection between arable land and food being a Western notion); and second, that the lack of land on Nauru was because it had been mined (or earmarked for mining) by colonial authorities, not because of inherent land scarcities or overuse of natural resources by local populations. Nauru is a single coral atoll that measures approximately six kilometres long and four kilometres wide; it has a total land area of approximately twenty one square kilometres (Gaiyabu 2007). Nauru has a circumference of twenty kilometres, making sea-borne food at least as important as land-borne food. Early maps of the island indicate mining plans covering over $75 \%$ of the land area, including all of the formerly-forested inland part of the island where important pandanus harvests and community food events took place (Kayser 1934). Most of these mines have now been emptied, leaving inhabitants to reside on around four square kilometres of flat, low-lying coastal rim of the island or area around the small, inland Buada Lagoon. Despite colonial powers formally agreeing to rehabilitate mined lands, this was never done. 
Comparison with other sources of evidence from the time also call Kirk's nutritional analysis into question. Australian reports of the time to the Council of the League of Nations and to the United Nations do not yield explicit results on the quantity, quality or nutritional value of the Nauruan diet. They do, however, contain information on the ration scale for prisoners for the years 1948-1955. Prisoners were given about 3.1 pounds of food per day (Appendix 1). It is surprising that Kirk’s assessment of Nauruan dietary intake is half that of prisoner rations at the time, and this may reflect significant shortcomings of Kirk’s survey. ${ }^{6}$

Like Bray, Kirk made a series of recommendations to improve the Nauruan diet. She proposed a decrease in sugar intake and an increase in the consumption of milk as a source of calcium, protein, riboflavin and vitamin A. She noted that powdered whole milk was cheap and easily available, but only minimally consumed compared to evaporated milk or sweetened condensed milk. This was likely tied to taste, status and global trade, as some products were more easily available on Nauru, and to Nauruans, than others. She also suggested restricting the importation of white rice, which is in line with Bray’s recommendation to introduce brown rice into the diet. Finally, Kirk recommended addressing the dietary problems through education such as cooking classes and lessons on nutrition, both involving the use of imported foods and colonial techniques. Overall, Kirk’s recommendations are similar to Bray’s, which suggests that interventions were not successfully made over a thirty year period (Table 1).

\footnotetext{
${ }^{6}$ Prisoner rations at the time were likely to be consistent and could be measured reliably (as they were institutionalised); they are therefore a good benchmark for what is required for survival in a particular setting.
} 


\section{Zimmet and Ringrose's survey (1979): investigating diabetes emergence}

In the 1970s, DR-NCDs began to be a concern on Nauru. By this time, Nauru had become politically independent. Two researchers went to carry out dietary research in Nauru, following earlier work on the epidemiology of diabetes on the island. Paul Zimmet was an Australian diabetologist who sought to investigate the high reported prevalence of diabetes in the Pacific islands (Zimmet 2010). Helen Ringrose was the Chief Dietician in the Department of Nutrition and Dietetics at the Royal Southern Memorial Hospital in Melbourne, Australia.

As a part of their large diabetes survey, Zimmet and Ringrose collected dietary data from 77 adult Nauruans (aged 20 years or over, 43 females and 34 males) who were selected at random from a larger random sample of 417 people attending the medical clinic. They selected this age group as they hypothesised that 'eating and drinking habits would be stabilised by that time'. It is neither clear why diet might be considered unstable before that time, nor why it might not change further throughout the lifecourse. They had 45-minute interviews with each subject, during which they collected subjects' medical histories, biological markers (including blood glucose levels) and baseline characteristics. They carried out a standard twenty four-hour dietary recall method to assess ‘routine meal pattern’ for the past twenty four hours, and presented participants with a food check-list based on Nauruan purchasing patterns to ascertain each person's past seven days of food consumption. Finally, the researchers measured bowl, cup and spoon sizes in participants' kitchens in order to estimate approximate quantities of foods and portion sizes. This uncritical use of a dietary survey practice based on Western notions of 'diet' suggests the researchers did not take cultural difference into account. While this method assumes that the people of Nauru use kitchenware in similar ways to Australia, ethnographic evidence from eleven months of participant observation 
fieldwork amongst the Nauruan community suggests this may not be the case. For example, it is common practice in contemporary Nauru to use small plates for an individual serve of food, but balance large quantities of food onto it, in a feat that almost defies possibility (McLennan 2013).

During life history interviews in 2010-11, participants who recalled the tests described not knowing what the researchers would do with the samples, reflecting a colonial model of medical survey. This was not unique to Nauru: Ulijaszek’s interviews with people on Rarotonga, Cook Islands, who had been surveyed by Zimmet were equally curious about what had happened to all the blood samples they had given. On Nauru, this led to not only curiosity, but fear. As one Nauruan explained,

Because he was in the research area, Paul, Paul Zimmet. And he even... Nauru[ans] even volunteered as guinea pigs for his programmes! So it was announced in the world news that, 'oh, the Nauru President signed an agreement that the new drugs for that would be tested on the Nauruans. Yeah (laughs). I remember that much, cos it was a... sort of a frightening thing to me. I said... cos I... every day, I tell some people, I said, 'you know what?! We're guinea pigs! You know what they did?! It's in the world news! That his ah... multi-drug resistant to diabetes and all this new gadgets or drugs. We take it. We have to take it! (Gigi) Fear kept many Nauruan people away from the researchers, and they described hiding from the clinic in order to avoid the tests. It is unclear how this may have biased the sample, or affected future health behaviours and trust in medical treatment.

Based on their survey, Ringrose and Zimmet found that Nauruans consumed 6,092 calories per day: 217 grams of protein, 210 grams of fat and 777 grams of carbohydrates. They described an example typical daily diet that included snacking 
habits and commonly consumed beverages. This reflects changes in Western dietary practice and adoption of 'snacking' as a socially-acceptable activity through the middle of the $20^{\text {th }}$ century (McLennan et al. 2015). At this time, food processing companies created new need for new food products in spaces between meals; they encouraged good mothers to give their children sufficient snacks, and began marketing a colourful explosion of new and novel snack foods. In Nauru, the researchers found that biscuits, breakfast cereals, canned foods and leftovers from the midday meal were consumed as 'snacks' throughout the day. Beverages such as sodas and beer were included in this assessment; these were not mentioned in Bray or Kirk’s studies, although historical ethnographic records suggest that sweet coconut toddy, a pandanus cordial-like drink, and sweetened condensed milk were each consumed regularly as sweetened beverages, the former two likely even in pre-colonial times (Kayser 1917; Kayser 1934). Moreover, unlike the previous two surveys, there is no quantified breakdown of the foods consumed. Results for frequency of intake (Table 1) are therefore an estimation based on Ringrose and Zimmet’s descriptions.

\section{Discussion}

\section{It is unclear whether caloric intake or imported food products increased in the second half of the twentieth century}

Comparing the three surveys indicates some changes in dietary intake over time, but raises questions about whether total calories have, in fact, risen in Nauru since the 1920s (Table 1). There is a higher caloric intake in the latest survey compared to the first two, but our analysis strongly suggests that that both Kirk and Bray may have significantly underestimated total caloric intake. Bray did not include sugar in his daily estimate of caloric intake because he did not believe it to be an 'everyday commodity'; 
however, he did make clear that it was a commonly-consumed item. As Kirk's methods were not specified, we cannot point to the reason why the daily weight intake she reported is far below contemporary prisoner rations (Appendix 1). However, given the political context at the time, with the people of Nauru starting to fight strongly for political independence, it is difficult to imagine that people would have been immediately open, trusting and honest with her. This is especially likely given she represented a foreign government that had power over the island and its inhabitants, and whose practices included curfews and strict policing. In addition, some of their foods or eating habits may have fallen outside of her assumed categories of consumption. If her food weight estimates are low, it is likely that the caloric intake is underestimated as well.

Overall, close analysis of historical surveys suggest that caloric intake has not changed as suddenly as hypothesised by some theorists of obesity and diabetes emergence. Both Bray and Kirk may have significantly underestimated dietary intake by focusing predominantly on 'traditional' food types and looking for food intake patterns that mirrored their own cultural understanding of the way food should be consumed. Kirk's results in particular, and the observation that they are significantly lower than prisoner rations at the time, suggests that she may have missed considerable amounts of food consumption amongst Nauruan people. Foods that could not easily fit into researchers' survey structures may have been missed or underreported. One particularly salient example is Bray's treatment of sugar - as it was not considered a proper foodstuff, it was left out of his final analysis of nutritional intake.

The dietary surveys available were designed and delivered by people who had very little ongoing contact with the local population. Errors introduced by assuming that human societies all treat food in similar ways may be further emphasised by the survey-style 
approaches taken by all of the researchers discussed - it is difficult for them to see anything that the people of Nauru may not want seen. More recent research indicates that the people of Nauru are quite shy; some explained that they did not like government surveys or researchers but had learned 'which answers to give people to make them happy and get rid of them as quickly as possible’ (McLennan 2013). In 2010, this included over-reporting fruit and vegetable consumption (which respondents knew nutritionists encouraged people to eat) and under-reporting foods they felt they had been told not to eat (e.g. doughnuts) or did not consider to be food (e.g. soft drinks).

Drawbacks of dietary recalls and interviews as a means of understanding typical diet have been discussed elsewhere (albeit without reference to sociocultural considerations) (Grandjean 2012); these often appear emphasised in non-Western settings being studied by Western researchers.

Moreover, contrary to the narrative that the diet changed substantially to favour processed, imported foods in the 1970s, the evidence points to these issues being prevalent much earlier. In 1927, Bray recommend a number of changes to the food environment (via regulating imports, given that the Nauruan diet was largely imported food), including prohibiting sugar and improving availability of high-fibre brown rice (Table 1$).{ }^{7}$ He also recommended some nutrition education and reduction of fat in the diet. Fifty years later, Ringrose and Zimmet made similar observations, which included a high-fat, low-fibre, high-imported diet. Yet they made no mention of structural or environmental changes. Over time, recommendations have focused less and less on structural or system-level change (e.g. Bray suggests banning sugar imports), and more

\footnotetext{
${ }^{7}$ Neither sugar nor rice have ever been cultivated on Nauru; the only 'traditional' staple carbohydrates recorded were the large array of pandanus and coconut products.
} 
on individual consumer behaviour (e.g. Zimmet and Ringrose focus on teaching nutrition). This reflects a growing emphasis on individualism and consumerism that we observe elsewhere - suggesting that Nauru was not isolated from global events or changing social values (see also McLennan \& Ulijaszek 2014a; Ulijaszek \& Mclennan 2016).

Comparing the historical survey recommendations to present-day recommendations demonstrates almost a century of failure of governments to implement dietary change on the island (Table 1). Over ninety years after Bray’s report, similar dietary recommendations continue to be made, emphasising the need for a shift to low-fat, high-fibre diets and for nutrition education. This implies an inability or unwillingness of governance structures and decision makers to act. In this setting, the former is unlikely: during the colonial period the Administrating authority ruled firmly in most aspects of Nauruan life (for example, by enforcing curfews, alcohol bans and strict segregation policies). Instead, it is possible that the protection of the local population did not go as far as protecting them from Australian imports.

\section{These surveys achieved three different objectives - none of which was improved health on the island}

Every survey carried out on Nauru has been for a specific purpose, beyond the more generic objective of improving outcomes for the people of Nauru. Two of the surveys Bray’s and Kirk’s - were highly politically-motivated and conducted. The Administration which employed the researchers had a stated mandate to demonstrate its ongoing care for the people of Nauru. Surveys therefore had to both paint a picture of a well cared-for local population, but also illustrate where the Administrative authority was improving the lives of the native population. Kirk's survey also came at a time of 
political change - following WWII many Pacific islanders, including the people of Nauru, began to work towards political independence. It was in Australia's interest to maintain control of the island for as long as possible, and so continue to demonstrate its relevance to the island nation. Ringrose and Zimmet, on the other hand, aimed to explain the recent emergence of DR-NCDs. Zimmet in particular hails his work on Nauru as being at a time when diabetes 'still had Cinderella status', and the example of Nauru was held up as an example to diabetes researchers all over the world (Zimmet 2010).

All three surveys achieved their aims, not only through what they included, but what they left out in their choice of food categories. Both Bray and Kirk omitted any investigation or mention of many of the imported foods being supplied to the local population, such as alcohol, which was being freely traded between colonists and the local population well before the time of their surveys (Stephen 1936) and throughout the 1900s (McLennan 2013). In addition, all three surveys omit colonial history. They fail to mention the deliberate dismantling of local foodways in order to facilitate large-scale colonial mining operations on the centre of the island that was once the place of pandanus harvest and celebrations (Kayser 1934). They do not take into account dietary change interventions being carried out by local missionaries and schools (Delaporte 1920). And, their accounts are markedly different from the import and export records kept and reported annually by the Administration (Administration of Nauru 1922; Commonwealth of Australia 1965).

There is no other available evidence that confirms the result of these dietary surveys. The survey methods are largely unclear, and there is very little alternative evidence upon which to base conclusions. Yet there is evidence that there was weak trust between locals and researchers: Nauruans today still remember the surveys, and in 2010-11 
recounted with glee the fun they had telling the researchers stories and the amount of information that they would 'believe'. Others recalled how Nauruan people wouldn't even tell other Nauruan people their personal health information, let alone foreigners. As a public health nurse explained:

They know their [health survey] results are a little 'off', because it's really hard surveying here, people wouldn’t talk to or trust the Nauruans from other districts who were helping survey. 'You can’t just walk into someone's house and ask them personal stuff about their house and family life!’

No more in-depth social research was done to validate or confirm survey findings, or the categories used for data collection and analysis. Furthermore, seasonal investigations were not carried out, nor were studies carried out at night when the climate is cooler and many people are active, so any amount of material may have been inadvertently missed as a result of this. These studies include only small portions of the Nauru population; decades-long inferences about nutritional change and diabetes emergence have thus been made based on the responses of just over 250 people across a century (Ringrose \& Zimmet 1979), and re-used and re-cited without great reinterrogation (e.g. 11,34-36). This leaves a wide margin for error for the use and interpretation of such survey results.

Despite this, these studies have formed the basis of significant and confident dietary change and disease emergence theories. At best, this may prevent us from developing more accurate theory. For example, how might Ringrose and Zimmet’s theory of diabetes emergence change if they had have looked at historical and cultural sources and noted that imported, Westernised foods had been the norm in Nauru for a century, and that caloric intake has been fairly consistent over this period of time? At worst, this 
can result in theories that are discriminatory to local populations and unhelpful for building a foundation of trust and collaboration for health improvement (Diamond 2003).

\section{Categories in dietary surveys are political and cultural, rather than scientific}

Categories used in all three surveys, such as meals, reflect cultural biases and frames of the researchers, rather than the local population. Kirk uses Australian food composition tables as a reference point; Pacific composition tables were available from the 1960s, but Ringrose and Zimmet continue to use the Australian version. The ethnographic evidence referenced above suggests that the neglect of local meanings and everyday practices can lead to problematic conclusions. At other times, data that may be very relevant can be discarded by researchers if it does not fit into their categories, as is the case with Bray's categorisation of sugar (12) and Ringrose and Zimmet's treatment of snacking items (8). Likewise, social relations are also often overlooked, despite being closely tied to food. Ruby Thoma, a Nauruan nurse who, in the 1990s, set up the Department of Public Health in Nauru, recalled one experience clearly. One of the first tasks of the new Public Health Department was to carry out a health survey. Among other things, they asked people to record their daily activities in a diary. One lady wrote that she went and visited one person, then another, and suddenly the day was over! People had all been surprised when they looked at what they had recorded in their daily activity logs, but they also asked her, 'if all of my time is full of socialising, then where am I supposed to fit anything else?!' Despite this initial observation - which was overlooked by researchers who focused on practices relating to diet and physical activity - the value of social exchanges has never been properly considered in research about Nauruan health. Interrogating, rather than overlooking, powerful observations like this may have helped us to make progress on persistent issues we now know are related 
to sociality, including mental health, suicide, obesity and loneliness.

Moreover, sociocultural evidence indicates that the people of Nauru are typically shy of foreigners, and locals explained how they had learned the 'right' things to say to ensure they minimised the length of any compulsory interactions with people carrying out health surveys (ironically, this demonstrated a reasonably good understanding of nutritional guidelines). Such differences in the perception and categorisation of foods suggests that dietary change is not so much about a shift from 'traditional' to 'modern' foods, but needs to take into account how such categories are shaped by the political, economic and historical context in which certain foods become more accessible and normalised than others. The problem of dietary change is rooted firmly in power and colonialism.

It is unsurprising that the results from dietary surveys have contributed to the narrative linking obesity and DR-NCDs to the uptake of Western goods and replacement of 'traditional' foods. However, in focusing on studying individual units of consumption (individuals, households, communities), surveys imply that change results from the decisions and actions of these units of analysis. They do not leave room for thinking about system-wide changes and structural forces - geopolitical, economic, social or other powerful influences - that might have a profound effect on people’s health.

\section{Conclusion}

Dietary change with nutritional implications considered to be relatively recent - such as the consumption of high-fat, low-fibre diets and the transition to imported foods occurred a century ago on Nauru. Despite this, Zimmet and Whitehouse (1987) state that it was only with political independence in 1968 that an unbelievable burst of consumerism and modernisation was unleashed. There is limited evidence that caloric 
intake overall has increased significantly over the past century. Our analysis shows that nutritional change in Nauru has a much longer history than suggested by recent grand theories of dietary change both there and on other Pacific islands. This is evidenced by continued recommendations, made by Bray in the 1920s, and again by Kirk in the 1950s, that Nauruans should increase their intake of fibre and reduce their consumption of carbohydrates and sugar. Based on how often these recommendations were made and the evidence that suggests they were either ignored or ineffective, we can conclude that dietary issues in Nauru have predated the import of high-energy Western food in the middle of the $20^{\text {th }}$ century.

Our findings point to several practical ways forward for DR-NCD intervention, all of which would involve a more holistic and collaborative interdisciplinary approach, and we discuss three briefly here. First, people studying nutritional change and designing nutrition interventions could interrogate, rather than simply accept, the generalisations and assumptions upon which their work, and the work of their predecessors, is founded. This includes assumptions about the reasons people behave the way they do and assumptions about what might be best for people (e.g. the notion of "development”, or ideas about what constitutes "good food”). Importantly, it also includes questioning current ideas of 'nutrition transition', where evidence does not necessarily seem to strongly support the idea of increasing caloric intake over time. This could be achieved through working closely with disciplines whose role it is to critically analyse our own cultural assumptions and biases, such as anthropology, history and the arts.

Second, our analysis indicates that forms of measurement used in surveys used to design, monitor or evaluate nutrition interventions need to be assessed and re-designed. Cultural biases in food categorisations, such as meals and portion sizes, likely led to erroneous estimates in all the surveys considered here. A focus only on some food types 
and data collection tools, rather than on other forms of evidence (such as import records or social histories) can also lead to unreliable results. Further, our concern is not just about past measurements themselves, but the ideas and assumptions that underpin and arise out of those measurements, which have had an effect on how food, nutrition and consumption become problematised in contexts of high DR-NCD prevalence. Assumptions such as that of 'energy balance' in relation to obesity production continue to be used unquestioningly when there is little direct evidence that such bodily reductionism holds true when social, ecological, psychological and physiological factors are considered (e.g. see Ulijaszek 2017; Ulijaszek \& Mclennan 2016), and this stronglyheld cultural framing of the body can inhibit rather than progress understanding of DRNCDs.

By comparing ethnographic and sociocultural evidence with historical surveys, and the cultural, political and normative contexts in which they were taken, our analysis points to the need for more holistic explanations for dietary change that take individual as well as social-structural factors into account. Currently, public health interventions do not reflect this, and may lack accuracy or relevance as a result. Instead, surveys and their (re)interpretation continue to privilege researcher inference and cultural values over the lived experiences of local populations, and reflect ongoing power imbalances. Long histories of failure to intervene effectively, in turn, can have unintended consequences including shame, stress, stigma (Brewis et al. 2011; Brewis 2014), reinforced inequality (Offer et al. 2010; Offer et al. 2012; Wisman \& Capehart 2012), community division (McLennan 2017), and/or ambivalence towards nutrition education messaging (Maio et al. 2007; Ulijaszek \& Mclennan 2016).

Third, interventions could better consider that current dietary patterns have long histories of deliberate action and inaction by global powers - governments and others. 
As a result, they are unlikely to be changed by telling individuals to change. Indeed, a focus on individual blame risks unwanted and unintended consequences discussed above. Alternatively, we may learn valuable lessons from understanding what has succeeded in changing dietary patterns over history (e.g. framing some foods and consumption patterns as high-status) and what has not (e.g. inaction on trade policy).

Our work and others' demonstrates that dietary factors leading to subsequent increases in obesity and obesity related non-communicable diseases on Nauru and elsewhere in the Pacific Islands are more complex than has been suggested in the nutritional and biological sciences. Indeed, the evidence indicates that obesity and DR-NCD in Nauru are first and foremost outcomes of politics, with roots in power relations and economic imperatives, such as uneven trade relations and monopolies over land. Yet it was convenient for Kirk to suggest in the 1950s that the land in Nauru was not fertile. This conclusion helped build Australia's case for not assisting in rehabilitating mined land, and it also implied that Australia was doing Nauruans a favour by importing foods to them. Today, the people of Nauru are blamed for consuming significant amounts of imported food; many still recall the ecological changes that occurred under colonial rule and so interpret dietary interventions from the same former colonial powers with incredulity or confusion. This underlines the importance of not only studying the social values and cultural context of the target population, but also the scientists doing the research.

Understanding history and social change is important for explaining the emergence of obesity and diet-related non-communicable diseases (DR-NCDs) (McLennan \& Ulijaszek 2014a). This includes understanding the culture of the people investigating nutrition and formulating nutrition policy and interventions, alongside that of the target population. Our analysis reveals considerable contradictions between the claims to 
‘scientific objectivity’ of researchers in this field, and the wide space for bias, interpretation and cultural assumptions to creep into survey design, delivery, (re)analysis and reporting - intentionally or unintentionally. Misalignment between ethnographic evidence - which suggests a long history of ongoing nutritional change and failure to intervene effectively - and survey data raises questions about the validity of research about human nutrition and nutritional change based solely on survey and quantitative data. This may help to explain chronic and long-term failure of nutrition policy and government intervention in the region. While it may feel challenging for scientists to question their own long-held assumptions by incorporating perspectives from other fields, doing so would open the way for the development of innovative approaches for addressing the ongoing DR-NCD burden on islander communities.

\section{Acknowledgements}

The authors are grateful for the generous assistance, advice and support of the people of Nauru.

\section{Declaration of interest statement}

None. 


\section{References}

Administration of Nauru. 1922. Report on the administration of Nauru, 17th December 1920 to 31st December 1921 (prepared by the Administrator for submission to the League of Nations). Melbourne: Printed and published for the Government of the Commonwealth of Australia by Albert J. Mullett, Government Printer. National Library of Australia, Nq 354.968 AUS.

Balkau B, King HO, Zimmet PZ, Raper LR. 1985. Factors associated with the development of diabetes in the Micronesian population of Nauru. Am J Epidemiol [Internet]. 122:594-605. Available from: http://www.ncbi.nlm.nih.gov/pubmed/3895898

Bray GW. 1927. Dietetic deficiencies and their relationship to disease: with special reference to vitamin B deficiency in the feeding of infants.

Brewis AA. 2014. Stigma and the perpetuation of obesity. Soc Sci Med [Internet]. [cited 2014 Dec 17]; 118:152-8. Available from:

http://www.ncbi.nlm.nih.gov/pubmed/25124079

Brewis AA, Wutich A, Falletta-Cowden A, Rodriguez-Soto I. 2011. Body norms and fat stigma in global perspective. Curr Anthropol. 52:269-276.

Carter K, Soakai TS, Taylor R, Gadabu I, Rao C, Thoma K, Lopez AD. 2011. Mortality trends and the epidemiological transition in Nauru. Asia-Pacific J Public Heal. 23:1023.

Collins VR, Dowse GK, Zimmet PZ. 1990. Prevalence of obesity in Pacific and Indian Ocean populations. Diabetes Res Clin Pract. 10:S29-32.

Commonwealth of Australia. 1965. Administration of the Territory of Nauru (1st July 1964 to 30th June 1965). Report to the General Assembly of the United Nations.

Sydney: Government Printer.

Commonwelath of Australia. 1991. Recommended Dietary Intakes for Use in Australia [Internet]. Available from:

https://www.nhmrc.gov.au/_files_nhmrc/publications/attachments/n6.pdf

Curtis M. 2004. The obesity epidemic in the Pacific islands. J Dev Soc Transform. $1: 37-42$. 
Delaporte PA. 1920. The men and women of old Nauru. The Mid-Pacific.:153-156.

Diamond J. 2003. The double puzzle of diabetes. Nature. 423:599-602.

Finucane MM, Stevens GA, Cowan MJ, Danaei G, Lin JK, Paciorek CJ, Singh GM, Gutierrez HR, Lu Y, Bahalim AN, et al. 2011. National, regional, and global trends in body-mass index since 1980: systematic analysis of health examination surveys and epidemiological studies with 960 country-years and 9·1 million participants. Lancet [Internet]. [cited 2013 Nov 7]; 377:557-67. Available from:

http://www.ncbi.nlm.nih.gov/pubmed/21295846

Gaiyabu M. 2007. Ekereri in the lives of teachers, parents and pupils: a path to school effectiveness and improvement in Nauru. [place unknown]: Thesis submitted for the degree of Doctor of Philosophy in Education, Faculty of Education, University of Cambridge.

Government of Nauru, World Health Organisation. 2007. Nauru NCD Risk Factors STEPS Report. Suva: World Health Organisation Western Pacific Region (WHOWPR). Grandjean AC. 2012. Dietary Intake Data Collection: Challenges and limitations. Nutr Rev. 70:101-104.

Grant AMB. 1933. A medical survey of the island of Nauru. Med J Aust. 1:113-118. Kayser PA. 1917. Die Eingebornen von Nauru (Sudsee). Eine kritische Studie. Anthropos. 12/13:313-337.

Kayser PA. 1934. Der Pandanus auf Nauru. Anthropos. 29:775-791.

Kirk NE. 1957. Dietary survey of the U.N. Trust Territory of Nauru. Canberra: Nutrition Section, Commonwealth Department of Health (at the request of the Department of Territories).

Maio GR, Haddock GG, Jarman HL. 2007. Social psychological factors in tackling obesity. Obes Rev. 8:123-125.

McLennan AK. 2013. An ethnographic investigation of lifestyle change, living for the moment, and obesity emergence in Nauru. [place unknown]: University of Oxford. McLennan AK. 2017. Local food, imported food, and the failures of community gardening initatives in Nauru. In: Wilson M, editor. Postcolonialism, Indig Struggl food sovereignty Altern food networks Subalt spaces. Oxford: Routledge; p. 127-145. 
McLennan AK, Ulijaszek SJ. 2014a. Obesity emergence in the Pacific islands: why understanding colonial history and social change is important. Public Health Nutr [Internet]. [cited 2014 Aug 29]. Available from: http://www.ncbi.nlm.nih.gov/pubmed/25166024

McLennan AK, Ulijaszek SJ. 2014b. Obesity emergence in the Pacific islands: why understanding colonial history and social change is important. Public Health Nutr [Internet]. 18:1-7. Available from: http://www.ncbi.nlm.nih.gov/pubmed/25166024 McLennan AK, Ulijaszek SJ, Eli K. 2015. Social aspects of dietary sugars. In: Goran MI, Tappy L, Lê K-A, editors. Diet Sugars Heal From Biol to Policy. Abingdon: Taylor and Francis / CRC Press; p. 1-11.

Nauru Bureau of Statistics, Secretariat of the Pacific Community, Macro International Incorporated. 2009. Nauru 2007 Demographic and Health Survey. Noumea: Secretariat of the Pacific Community.

Neel J. 1962. Diabetes mellitus: a "thrifty” genotype rendered detrimental by “progress”? Am J Hum Genet. 14:353-362.

Offer A, Pechey R, Ulijaszek SJ. 2010. Obesity under affluence varies by welfare regimes: the effect of fast food, insecurity, and inequality. Econ Hum Biol. 8:297-308.

Offer A, Pechey R, Ulijaszek SJ, editors. 2012. Insecurity, inequality and obesity in affluent societies. Oxford: Oxford University Press.

Pollock NJ. 1992. These roots remain: food habits in islands of the Central and Eastern Pacific since Western contact. Honolulu: University of Hawaii Press.

Pollock NJ. 1995. Chapter 3: Social fattening practices in the Pacific. In: De Garine I \& Pollock N. Social Aspects of Obesity. London: Taylor and Francis.

Pollock NJ. 2014. Nauru phosphate history and the resource curse narrative. J Soc Océanistes 138-9: 107-119.

Popkin BM. 1998. The nutrition transition and its health implications in lower-income countries. Public Health Nutr [Internet]. 1:5-21. Available from: http://www.ncbi.nlm.nih.gov/pubmed/10555527

Popkin BM, Adair LS, Ng SW. 2012. Global nutrition transition and the pandemic of obesity in developing countries. Nutr Rev. 70:3-21. 
Ringrose H, Zimmet PZ. 1979. Nutrient intakes in an urbanized population with a high diabetes prevalence. Am J Clin Nutr. 32:1334-1341.

Scott J. 2015. Dietitians Association of Australia 32nd national conference: Lecture in Honour of Nancy Hitchcock. Nutr Diet. 72:377-380.

Secretariat of the Pacific Community. 2006. Pandanus. Pacific food leaflet number 6.

Stephen EMH. 1936. Notes on Nauru. Oceania. 7:34-63.

Taylor R. 2011. The double disease burden in the Pacific Islands. In: Lewis MJ, MacPherson KL, editors. Heal Transitions Double Dis Burd Asia Pacific Hist Responses to Non-Communicable Commun Dis. London: Routledge; p. 1-27.

Taylor R, Thoma K. 1985. Mortality patterns in the modernized Pacific Island nation of Nauru. Am J Public Health. 75:149-55.

Ulijaszek SJ. 2007. Frameworks of population obesity and the use of cultural consensus modeling in the study of environments contributing to obesity. Econ Hum Biol. 5:44357.

Ulijaszek SJ (2017). Models of Obesity. From Ecology to Complexity in Science and Policy. Cambridge: Cambridge University Press.

Ulijaszek SJ, Koziel S. 2007. Nutrition transition and dietary energy availability in Eastern Europe after the collapse of communism. Econ Hum Biol. 5:359-369.

Ulijaszek SJ, Mclennan AK. 2016. Framing obesity in UK policy from the Blair years, 1997-2015: The persistence of individualistic approaches despite overwhelming evidence of societal and economic factors, and the need for collective responsibility. Obes Rev. 17:397-411.

Viviani N. 1970. Nauru: phosphate and political progress. Canberra: Australian National University Press.

Wedgewood CH. 1936a. Report on research work in Nauru Island, Central Pacific (Part 1). Oceania. 6:359-391.

Wedgewood CH. 1936b. Report on research work in Nauru Island, Central Pacific (Part 2). Oceania. 7:1-33.

Weeramantry C. 1992. Nauru. Environmental damage under international trusteeship. Oxford: Oxford University Press. 
Wilson M, editor. 2017. Postcolonialism, indigeneity and struggles for food sovereignty: Alternative food networks in subaltern spaces. London: Routledge. Win Tin ST, Lee CMY, Colagiuri R. 2014. A profile of diabetes in Pacific Island Countries and Territories. Diabetes Res Clin Pract [Internet]. [cited 2014 Dec 12]. Available from: http://www.sciencedirect.com/science/article/pii/S0168822714004707 Wisman JD, Capehart KW. 2012. Creative destruction, economic insecurity, stress, and epidemic obesity. In: Offer A, Pechey R, Ulijaszek SJ, editors. Insecurity, Inequal Obes Affl Soc. Oxford: Oxford University Press; p. 11-53.

Zimmet PZ. 2010. A lifetime pursuit of diabetes through chance. Med J Aust. 191:63236.

Zimmet PZ and Whitehouse S (1987) Pacific islands of Nauru, Tuvalu and Western Samoa. In: Trowell H and Burkitt D (eds) Western Diseases: their emergence and prevention. London: Edward Arnold. Pp. 204-224. 


\section{Appendices}

Appendix 1. Daily prisoner rations in Nauru on 1955, compared to daily household intake of foodstuffs recorded by Bray (1927) and Kirk (1957). Comparable data are not available from the 1979 study. For the sake of comparison, the values in bold have been calculated by converting weekly consumption (measured in pounds) to daily consumption (measured in ounces).

\begin{tabular}{|c|c|c|c|}
\hline & $\begin{array}{c}\text { Individual } \\
\text { daily } \\
\text { consumption } \\
(1927)\end{array}$ & $\begin{array}{l}\text { Prisoner rations on Nauru } \\
\text { (1955) }\end{array}$ & $\begin{array}{c}\text { Amount consumed } \\
\text { per head per day } \\
\text { (1957) }\end{array}$ \\
\hline Coconut Milk & $50 \mathrm{oz}$. & & \\
\hline Toddy & $40 \mathrm{oz}$. & & $2.6 \mathrm{oz}$. \\
\hline Grated Coconut & $8 \mathrm{oz}$. & & \\
\hline Fish & $12 \mathrm{oz}$. & 16 oz. (two days a week) & $0.23 \mathrm{oz}$. \\
\hline Pandanus & $30 \mathrm{oz}$. & & \\
\hline Biscuits & $2 \mathrm{oz}$. & & \\
\hline Meat & & 12 oz. (five days a week) & $3.2 \mathrm{oz}$. \\
\hline Rice & & $7 \mathrm{oz}$. & $5.7 \mathrm{oz}$. \\
\hline Butter & & & $1.1 \mathrm{oz}$. \\
\hline Sugar & & $4 \mathrm{oz}$. & $6.4 \mathrm{oz}$. \\
\hline Cereal & & 4 tablespoons & $0.23 \mathrm{oz}$ \\
\hline Vegetables & & 2 teaspoons & $1.37 \mathrm{oz}$. \\
\hline Milk & & $3.5 \mathrm{oz}$. & $3.2 \mathrm{oz}$. \\
\hline Bread & & $8 \mathrm{oz}$. & $3.4 \mathrm{oz}$. \\
\hline Onion & & $2 \mathrm{oz}$. & \\
\hline Dripping & & 1.5 oz. (weekly) & \\
\hline Potatoes & & $2.3 \mathrm{oz}$. & $0.07 \mathrm{oz}$. \\
\hline Tea & & $0.8 \mathrm{oz}$ & $.114 \mathrm{oz}$. \\
\hline Total & $4.4 \mathrm{lbs}$ & $3.1 \mathrm{lb}$ & $\begin{array}{r}1.7 \mathrm{lb} \text { (Kirk } \\
\text { reported } 1.66 \\
\mathrm{lb} / \text { day) } \\
\end{array}$ \\
\hline
\end{tabular}




\section{Tables}

Table 1: Summary of dietary survey researchers, methods and results.






\begin{tabular}{|c|c|c|c|c|}
\hline & & & $\begin{array}{l}\text { accurate figure might be } \\
\text { double (or more) of this } \\
\text { reported estimate (see } \\
\text { also Appendix } 1 \text { ). }\end{array}$ & this. \\
\hline  & $\begin{array}{l}\text { Recommendation } \\
\text { s made }\end{array}$ & $\begin{array}{l}\text { Food environment } \\
\text { Import only brown rice } \\
\text { Import wholemeal flour } \\
\text { as staple cereal } \\
\text { Prohibit sale of sugar } \\
\text { Introduce sweet } \\
\text { potatoes } \\
\text { Dietary education } \\
\text { Increase egg } \\
\text { consumption } \\
\text { Increase condensed milk } \\
\text { consumption } \\
\text { Increase Vitamin B (not } \\
\text { via pandanus) } \\
\text { Medical intervention } \\
\text { Use toddy dregs to } \\
\text { produce a Vitamin B } \\
\text { emulsion for children } \\
\text { Provide cod liver oil }\end{array}$ & $\begin{array}{l}\text { Food environment } \\
\text { Increase vegetable } \\
\text { import } \\
\text { Replace white rice with } \\
\text { brown rice } \\
\text { Increase powdered milk } \\
\text { supply (inc. Vitamin A } \\
\text { fortified) } \\
\text { Dietary education } \\
\text { Teach nutrition } \\
\text { Increase vegetable and } \\
\text { milk consumption }\end{array}$ & $\begin{array}{l}\text { Dietary education } \\
\text { Teach nutrition } \\
\text { Encourage local food } \\
\text { production }\end{array}$ \\
\hline
\end{tabular}


Table 2: Summary of additional dietary data. We use food rations for prisoners in the present paper.

\begin{tabular}{|c|c|c|c|}
\hline Data & Year(s) & Collected by & Collected for \\
\hline $\begin{array}{l}\text { Import values of food } \\
\text { and non-food items }\end{array}$ & $1924-1941$ & $\begin{array}{l}\text { The Parliament of the } \\
\text { Commonwealth of Australia }\end{array}$ & $\begin{array}{l}\text { Report to the League of } \\
\text { Nations }\end{array}$ \\
\hline $\begin{array}{l}\text { Import values of food } \\
\text { and non-food items }\end{array}$ & $1947-1956$ & Commonwealth of Australia & $\begin{array}{l}\text { Report to the United } \\
\text { Nations }\end{array}$ \\
\hline $\begin{array}{l}\text { Percent of total food } \\
\text { and non-food items }\end{array}$ & 1947-1956 & Commonwealth of Australia & $\begin{array}{l}\text { Report to the United } \\
\text { Nations }\end{array}$ \\
\hline Origin of imports & 1948-1955 & Commonwealth of Australia & $\begin{array}{l}\text { Report to the United } \\
\text { Nations }\end{array}$ \\
\hline $\begin{array}{l}\text { Total value of imports } \\
\text { and exports }\end{array}$ & $1923-1940$ & $\begin{array}{l}\text { The Parliament of the } \\
\text { Commonwealth of Australia }\end{array}$ & $\begin{array}{l}\text { Report to the League of } \\
\text { Nations }\end{array}$ \\
\hline $\begin{array}{l}\text { Total value of imports } \\
\text { and exports }\end{array}$ & 1947-1955 & Commonwealth of Australia & $\begin{array}{l}\text { Report to the United } \\
\text { Nations }\end{array}$ \\
\hline $\begin{array}{l}\text { Food rations for } \\
\text { prisoners }\end{array}$ & $1948 ; 1952-55$ & Commonwealth of Australia & $\begin{array}{l}\text { Report to the United } \\
\text { Nations }\end{array}$ \\
\hline $\begin{array}{l}\text { Food rations for } \\
\text { tradesmen }\end{array}$ & $\begin{array}{l}1948 ; 1949 ; \\
1954 ; 1956\end{array}$ & Commonwealth of Australia & $\begin{array}{l}\text { Report to the United } \\
\text { Nations }\end{array}$ \\
\hline $\begin{array}{l}\text { Food rations for } \\
\text { boatmen and labourers }\end{array}$ & $1954 ; 1956$ & Commonwealth of Australia & $\begin{array}{l}\text { Report to the United } \\
\text { Nations }\end{array}$ \\
\hline
\end{tabular}

